\title{
Sensitivity of Foreign Direct Investment to Monetary Policy Dynamics in Nigeria
}

\author{
Ogbonna, Udochukwu Godfrey Ph.D ${ }^{1}$ Ejem, Chukwu Agwu, Ph.D ${ }^{2}$ \\ 1.Department of Management Science, Rhema University, Aba, Nigeria \\ 2.Department of Banking and Finance, Abia State University, Uturu, Nigeria
}

\begin{abstract}
Due to the recent slowdown in foreign direct investment in Nigeria, this study considered it necessary to look at the monetary policy dynamics of Nigeria to ascertain if there are gaps in transmission processes. The study made use of annual data from 1988 to 2019 on Foreign Direct Investment (FDI) and four other monetary policy variables; Liquidity Ratio, Monetary Policy Rate, Prime Lending Rate and Degree of trade Openness collected from the globaleconomy.com and Central Bank of Nigeria Statistical Bulletin to examine the relationship between Foreign Direct Investment (FDI) and monetary policy dynamics using Autoregressive Distributive Lags. The major findings are; that monetary policy rate and degree of trade openness have negative and significant relationship with foreign direct investment, while liquidity ratio and prime lending rate insignificantly relate to the foreign direct investment. However, since monetary policy rates is disclosed to significantly but negatively relate to foreign direct investment, the central bank of Nigeria should reduce further the rate in order to woo foreign investors to do more business in Nigeria. Again, since globalization and trade liberalization have totally removed the issue of countries being in the state of autarky (closed economy), most of the beggars thy neighbours policies should be discarded at least to enhance the degree of trade openness. The Central Bank of Nigeria should also conduct the monetary policy with the aim of encouraging foreign investment in Nigeria.
\end{abstract}

Keywords: FDI, Monetary Policy, ARDL, Nigeria

DOI: $10.7176 /$ RJFA/11-16-06

Publication date:August $31^{\text {st }} 2020$

\section{Introduction}

The concept of Foreign Direct Investment (FDI) encompasses the movement of capital which includes ownership and control, where ownership of production facilities took place. It can also be viewed from the standpoint of physical movement such as construction of factory or acquisition of lasting management interest in business venture by individuals, organization or even the government of one country in another country. For instance, when a Chinese buys ordinary share in Nigeria firm, the Chinese becomes owner as well possess element of control, since ordinary shares have voting rights as one of the attractive rights of the equity. For classification purposes, this type of purchase is accounted as FDI if the share involves more than ten percent of the outstanding ordinary share of the Nigerian firm. Again, assuming a Chinese firm buys more than fifty percent of the shares outstanding, it then acquires a controlling interest and the Nigerian firm becomes a foreign subsidiary. In similar scenario, if a Ghanaian builds a plant in Nigeria, it is also seen as FDI. This is because there is substantial ownership and control of the plant (new facility), a branch plant built by a Ghanaian. For more emphasis, in international finance, the concept of FDI is normally discussed under Multinational Corporation (MNC) or transnational corporation (TNC) or transnational enterprise (TNE). In this context, it entails production taking place in plants located in two or more countries but under the supervision and general direction of the headquarters located in one country. It can also be seen as an enterprise that manages production or delivers services in more than one country (Appleyard, Field and Cobb, 2008; Uma, 2010). The international Labour Organization (ILO) defined MNC as a corporation that has its management headquarters in one country, known as the home country (country of origin) and operates in several other countries, known as host countries (Ejem and Jombo, 2011).

There is need to differentiate FDI with foreign portfolio investment (FPI). FPI does not include ownership or control but has to do with the flow of what economists termed financial capital instead of real capital. Example of FPI is deposit of fund in Nigeria by a Chinese or may be purchase of bond (certificate of indebtedness, not certificate of ownership) of a Nigerian firm by a Mexican. These flows of financial capital have their immediate effects on balances of payments or exchange rates rather than on production or income generation (Appleyard, Field and Cobb, 2008). Having expatiated on the meaning of FDI, the thrust of this study is to evaluate the variables that influence the flow. For instance, Veugelers (1991) investigated the factors that influence FDI in the developed countries and found a positive significant relationship with gross domestic product (GDP) weighted by the degree of openness of the recipient country. Here, the emphasis is monetary policy, which is a measure designed by the government or the central bank to regulate and control volume, cost and direction of money and credit in the economy to achieve some specified macroeconomic policy objectives including performance of FDI and FPI, which can be changed from time to time depending on the economic 
position of a particular country (Osiegbu, 2006; Dare and Okeya, 2017).

The choice of monetary policy is that, it remains important tool that can stimulate growth and stability of financial institution in most developing economies. In Nigeria, the objectives usually include promoting monetary stability, strengthening the external sector performance such as FDI and FPI, also generating a sound financial system that will support increased output and employment (Onoh, 2002; Udude, 2014; Ndugbu and Okere, 2015; Dare and Okeya, 2017).The analysis and transmission of monetary policy by the central bank of Nigeria $(\mathrm{CBN})$ is aimed at facilitating the design of a suitable macroeconomic policy framework that triggers sustainable economic growth, domestic stability and external balance. An indispensable role of central bank is to exercise a firm control over money supply, generally considered the nerve centre of the economy (Onoh, 2007; Echekoba, Ananwude and Lateef, 2017).

Recently, foreign direct investment seems to have slowed down for foreign portfolio investment, especially from 2004 after the recapitalization of banking sector that opened up the capital market. Mostly, following heels of the introduction of the Investors and Exporters Foreign Exchange (IEFX) window in late April 2017 which is arguably the most important policy implemented by the central bank of Nigeria (CBN) in 2017. Prior to the introduction of the IEFX, foreign portfolio investors, particularly those repatriating funds from Nigeria, were concerned about the multiple exchange rates in the country. There was a huge gap between the official exchange rate and the parallel market exchange rate, plus an opaqueness in the foreign exchange management system (which caused uncertainty), and the acute scarcity of hard currency. Consequently, there was an exodus of foreign capital and little or no new foreign direct investments into the country. However, foreign portfolio investors returned with the opening of the IEFX. Prior to this, investors were of the view that the naira was overvalued and not at a market determined level. The IEFX window, higher oil prices and production, and the CBN's consistent intervention in the foreign exchange market are the main drivers of the stability and the convergence of exchange rates in Nigeria today (Central Bank of Nigeria, 2018).

This sluggish or cold feet developed by foreign investors about wholly owned investment or FDI is a matter of concern to the researchers, though Foreign Direct Investment in Nigeria increased by 427.76 USD Million in the first quarter of 2020 (UNCTAD, 2020). As a result, a lot of issues have cropped up in the minds of the researchers. Prominent among them is, whether the CBN monetary policy tools and mechanisms are not friendly with the foreign investors or otherwise. These concerns actually led to the conception of this study, sensitivity of foreign direct investment to monetary policy dynamics in Nigeria. The remaining sections of this study are organized as follows; section two will take care of review of related literature; section three addresses the materials and methods of analysis adopted; section four analyses the data, results and interpretation while section five handles conclusion and recommendations.

\section{Literature Review}

\subsection{Foreign direct investment (FDI) and Monetary Policy in Nigeria}

Notwithstanding, Nigeria is said to be the third host economy for FDI in Africa, behind Egypt and Ethiopia. The country is among the most promising poles of growth in Africa and attracts numerous investors in the sector of hydrocarbon, energy, buildings etc. The country undergoes the effects of the oil counter shock. FDI flows to Nigeria amounted to USD 3.3 billion in 2019 , showing a $48.5 \%$ decrease compared to the previous year (USD 6.4 billion in 2018) under the effects of austerity measures. The total stock of FDI was estimated at USD 98.6 billion in 2019. Some of the main investing countries in Nigeria include the USA, China, United Kingdom, the Netherlands and France (UNCTAD, 2020). Nigeria intends to diversify its economy away from oil by building a competitive manufacturing sector, which should facilitate integration into global value chains and boost productivity. The recent merging of trade, industry and investment under the auspices of the Federal Ministry of Industry, Trade and Investment reflects Nigeria's intention to effectively coordinate between these three key areas to improve its trading and investment environment. Some of the country's main advantages are a partially privatized economy, an advantageous taxation system, significant natural resources and a low cost of labour. Conversely, widespread corruption, political instability, lack of transparency and poor quality of infrastructure are limiting the country's FDI potential. Intense bureaucracy also curbs foreign investment. Nigeria ranked 131st worldwide for the ease of doing business, this represent a leap from 2019 edition when the country was ranked 146th. The country has improved in many subcategories of the rankings: starting a business, dealing with construction permits, getting electricity, registering property, trading across borders, and enforcing contracts. Nigeria appears as one of the top-10 improvers for the second time (doing business). Nigeria has been attracting strong inflows from American companies, including giants like Uber, and Facebook, as well as Emergent Payments, and Meltwater Group. China has also been investing considerably in the country, mainly in the textile, automotive and aerospace industries (World Bank's, 2020).

The Monetary Policy Committee (MPC) voted in May 2016 to adopt greater flexibility in ex-change rate policy and held other monetary policy parameters unchanged. This was the first in a sequence of monetary policies aimed at salvaging a near crisis situation in the foreign exchange (forex) market. The situation in the 
forex market was occasioned by a steep fall in global oil prices and domestic oil production shocks, and was exacerbated by economic policy inertia. The immediate effect of this new policy was that the average naira exchange rate weakened at the inter-bank segment of the foreign exchange market. Consequently, the exchange rate at the interbank market opened at N197.00/US\$ and closed at N292.90/US\$. The Central Bank of Nigeria $(\mathrm{CBN})$ further supported the measure by hiking the monetary policy rate by 200 basis points (bps) from $12.00 \%$ per annum (pa) to 14\% pa at the MPC meeting in July 2016. The rationale for the decision was to attract foreign portfolio investment into the country and stabilize the naira. The policy seemed to have worked as imported capital jumped by $74.84 \%$ from $\$ 1.04$ billion (bn) in the second quarter of 2016 (Q2'16) to \$1.82bn in Q3'16. Foreign Portfolio Investment (FPI) accounted for $85 \%$ of the total quarterly increase. The euphoria surrounding the flexible exchange rate and higher interest rate was short-lived as capital imported in Q4'16 declined by $15 \%$ to $\$ 1.55 \mathrm{bn}$ and was followed by a $41.36 \%$ fall in capital imported in Q1'17 to $\$ 908.27 \mathrm{mn}$. This was largely due to the skepticism about the flexible foreign exchange (forex) policy and investors' apprehension about the huge disparity between the interbank forex rate and the parallel market rate. This trend continued until the Investors Export Foreign Exchange window (IEFX) was launched in late April 2017 as already stated. The IEFX boosted liquidity in the forex market, calmed the frayed nerves of foreign investors and supported the convergence of Exchange rate.

\subsection{Theoretical Review}

Here, the researchers examined major ingredients of monetary policies that are likely to influence FDI; the Keynesian Theory: Keynesian Economists think of monetary policy as working primarily through interest rate. In Keynesian transmission mechanism, an increase in the money supply leads to a fall in interest rate to include the public to hold additional money balances. Consequently, a fall in interest rate may stimulate investment. The increased investments also increase the level of income or output through the multiplier, which may stimulate economic activities. Thus, monetary policy affects economic activity indirectly through their impact on interest rates and investment. Therefore, the Keynesian transmission mechanism is characterized by a highly detailed sector building up of aggregate demand and a detailed specification of portfolio adjustment process that attaches central role to interest as an indirect link between monetary policy and fiscal demand. In simple terms, the monetary mechanism of Keynesians emphasizes the role of money, but involves an indirect linkage of money with aggregate demand via the interest rate (Ekpung, Udude and Uwalaka, 2015). The Classical Monetary Theory: Dare and Okeya (2017) revealed that the evolution of this school of thought can be traced to great economists of the past, such as Jean Baptist Say, Adam Smith, David Ricardo, Pigou and others who shared the same beliefs. They believe that "supply creates its own demand" The classical economists decided upon the quantity theory of money as the determinant of the general price level. The theory shows how money affects the economy. The Monetarist Theory: As recorded by Ekpunget'al (2015), the Monetarist Economist recognize that money is not just a close substitute for a small class of financial assets but rather a substitute for large spectrum of financial and real asset. Given an equilibrium position, an increase in money supply raises the actual proportion of money relative to the desired proportion. The monetarist argument centers on the old quantity theory of money. If velocity of money in circulation is constant, variation in money supply will directly affect prices and output or income (GNP). According to Udude (2014), the monetarist essentially adopted Fisher's equation of exchange to illustrate their theory, as a theory of demand for money and not a theory of output price and money income by making a functional relationship between the quantities of real balances demanded a limited number of Variables. Monetarists like Friedman emphasized money supply as the key factor affecting the wellbeing of the economy. Thus, in order to promote steady of growth rate, the money supply should grow at a fixed rate, instead of being regulated and altered by the monetary authorities. Friedman equally argued that since money supply is substitutive not just for bonds but also for many goods and services, changes in money supply will therefore have both direct and indirect effects on spending and investment respectively such that demand for money will depend upon the relative rates of return available or different competing assets in which wealth can be.

Empirically, in support of the relationship between FDI and monetary policy, Rădulescu, Druică and Omran (2012) employed linear regression and VAR to investigate the Impact of the Monetary Policy Factors on the Foreign Direct Investments in Romania based on monthly data series during 2000-2010. This study focused mainly to test empirically the impact of the monetary policy factors on FDIs in Romania and to propose some directions for the Romanian macroeconomic policy. After a thorough empirical analysis, results revealed that monetary factors such as higher interest rates and higher inflation attracted FDIs in the last decade. It was also shown that the fiscal factors (mainly direct taxes) seemed to play a less important role. The paper recommended that Romania focus on improving the other non-financial factors that influence greatly the investment environment here (infrastructure, legal and political stability) in the long-run, after it enters in the euro-zone. In similar paper, using ordinary least square, Anna, et'al (2012) examined the relationship interest rate and FDI inflows in Zimbabwe with monthly data spanning from February, 2009 to June, 2011. The result of the study 
revealed that interest rate as a major monetary policy instrument had no significant impact on FDI inflows in Zimbabwe.

\section{Data and Methods}

\subsection{Data}

This study employed data that comprise of 32 annual observations (1988-2019) on Foreign Direct Investment (FDI) and four other monetary policy variables; Liquidity Ratio (LDR), Monetary Policy Rate (MPR), Prime Lending Rate (PLR) and Degree of trade Openness (DOP) collected from the globaleconomy.com and Central Bank of Nigeria (CBN) Statistical Bulletin.

The variables can be defined as follows;

Degree of trade openness is seen as the sum of imports and exports measured by Gross Domestic Product (GDP). Trade transactions are likely to generate cross-border financial flows including trade credits, export insurance, payment facilitation. It is one the gauge to know the extent to which a country is engaged in the global trading system. Trade openness is usually measured by the ratio between the sum of exports and imports and gross domestic product (GDP) (Policonomics, 2020; Investopedia, 2020)

\section{Degree of openness $=\frac{X+M}{G D P} * 100$}

Monetary Policy Rate (MPR) is the interest rate at which CBN lends to the commercial banks. The MPR is the benchmark against which other lending rates in the economy are pegged and is usually used as an instrument to moderate inflation in the economy (Investopedia, 2020). Hayes (2019) saw Liquidity ratios as an important class of financial metrics used to determine a debtor's ability to pay off current debt obligations without raising external capital. Liquidity ratios measure a company's ability to pay debt obligations and its margin of safety through the calculation of metrics including the current ratio, quick ratio, and operating cash flow ratio. Chen (2020) defined prime rate (prime) as the interest rate that commercial banks charge their most creditworthy customers, generally large corporations. The prime interest rate, or prime lending rate, is largely determined by the federal funds rate, which is the overnight rate that banks use to lend to one another

The time series plot of the data as shown in figure I below revealed that all the variables trended upwards and downwards with peaks and trough, suggesting non-stationarity of the variables.
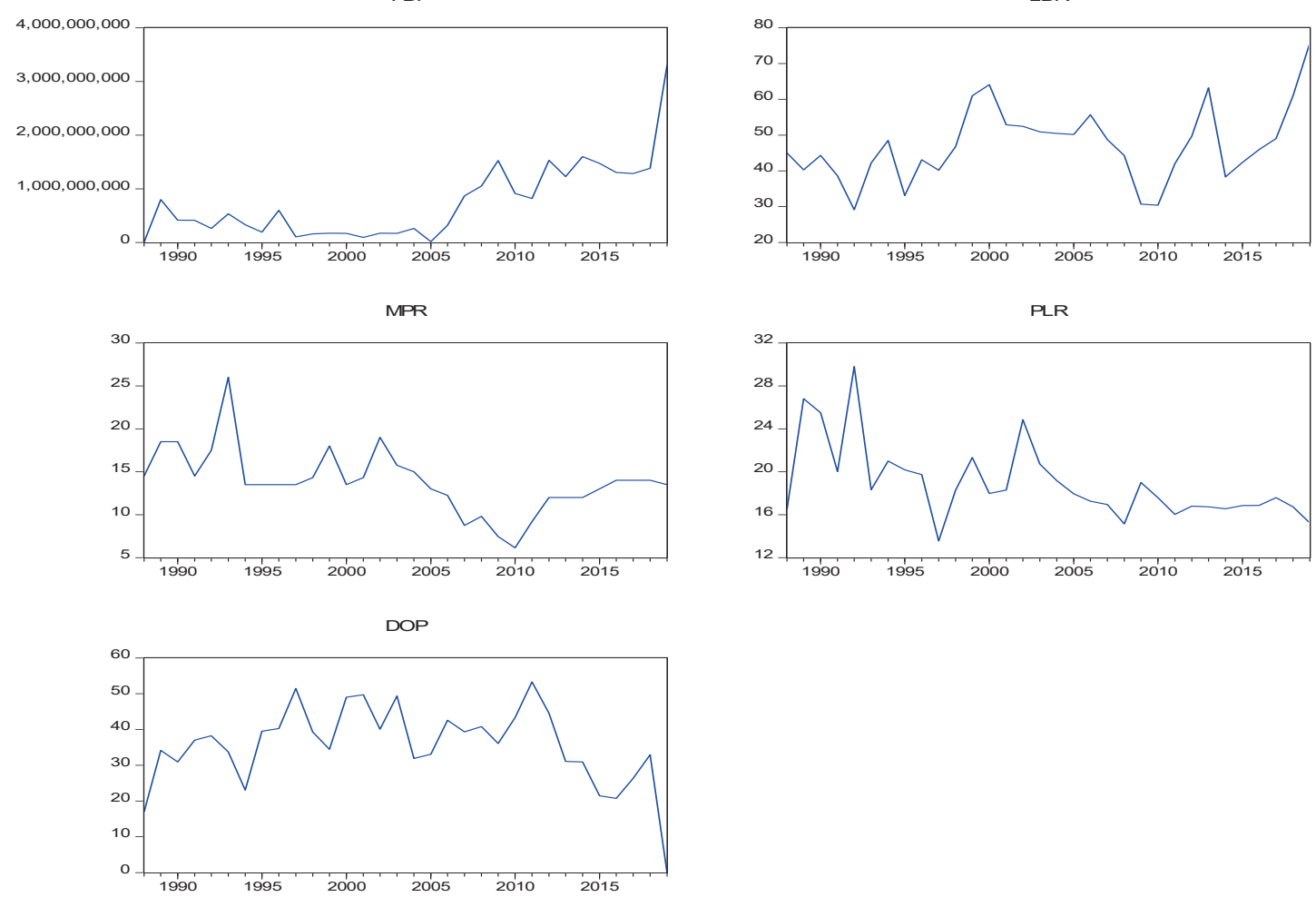

Figure 1: Time series of FDI, LDR, MPR, PLR and DOP

\subsection{Method and Model}

This study employed Augmented Dickey Fuller (ADF) unit root test to evaluate the stationarity of the variables. Correlation matrix is used to determine presence of multicollinearity, and other relevant techniques to examine 
and determine the global utility of the specified model. The relationship between Foreign Direct Investment (FDI) and monetary policy dynamics was examined with Autoregressive Distributive Lags (ARDL).

The empirical model is thus given as follows;

$F D I=\alpha_{0}+\alpha_{1} F D I_{t-1}+\alpha_{2} L D R+\alpha_{3} L D R_{t-1}+\alpha_{4} M P R+\alpha_{5} M P R_{t-1}+\alpha_{6} P L R+\alpha_{7} P L R_{t-1}+\alpha_{8} D O P+\alpha_{9} D O P_{t-1}+e_{t-1}$

Where, FDI $=$ Foreign Direct Investment, $\mathrm{LDR}=$ Liquidity Ratio, MPR $=$ Monetary Policy Rate, PLR $=$ Prime Lending Rate and DOP = Degree of trade Openness

\section{Empirical Results}

\section{1: Description of Variables}

Table 1 below shows the summary of statistical distributional features of all the variables employed. All the variables; FDI, LDR, MPR, PLR and DOP exhibited Kurtosis greater than 3, suggesting a leptokurtic distribution. FDI, LDR, MPR and PLR show positive skewness except DOP that parades a negative skewness. All the variables; FDI, MPR, PLR and DOP are abnormally distributed, except LDR that is normally distributed.

Table 1: Descriptive Statistics for FDI, LDR, MPR, PLR and DOP

\begin{tabular}{|l|c|c|c|c|c|}
\hline & FDI & LDR & MPR & PLR & DOP \\
\hline Mean & $7.33 \mathrm{E}+08$ & 47.19924 & 13.88875 & 18.91219 & 35.48000 \\
\hline Median & $4.74 \mathrm{E}+08$ & 46.37500 & 13.50000 & 17.96500 & 36.54000 \\
\hline Maximum & $3.30 \mathrm{E}+09$ & 75.80000 & 26.00000 & 29.80000 & 53.28000 \\
\hline Minimum & 5061000. & 29.10000 & 6.130000 & 13.54250 & 0.000000 \\
\hline Std. Dev. & $7.05 \mathrm{E}+08$ & 10.41731 & 3.741211 & 3.540121 & 11.09695 \\
\hline Skewness & 1.594379 & 0.526953 & 0.727437 & 1.426991 & -0.964270 \\
\hline Kurtosis & 6.371397 & 3.434473 & 5.172883 & 4.792966 & 4.640521 \\
\hline Jarque-Bera & 28.71266 & 1.732645 & 9.117443 & 15.14658 & 8.547437 \\
\hline Probability & 0.000001 & 0.420495 & 0.010475 & 0.000514 & 0.013930 \\
\hline Sum & $2.34 \mathrm{E}+10$ & 1510.376 & 444.4400 & 605.1899 & 1135.360 \\
\hline Sum Sq. Dev. & $1.54 \mathrm{E}+19$ & 3364.128 & 433.8963 & 388.5062 & 3817.410 \\
\hline Observations & 32 & 32 & 32 & 32 & 32 \\
\hline
\end{tabular}

Authors' computation output using E-view 10.

\subsection{Multicolinearity Test for FDI, LDR, MPR, PLR and DOP}

Table 2 below shows the correlation matrix of the variables, revealing that correlations between FDI, LDR, MPR, PLR and DOP range from -0.547054 to 0.511559 , suggesting that the variables are not linearly correlated. Therefore, the researchers have enough evidence to declare no presence of multicollinearity in the model.

Table2: Correlation Matrix

\begin{tabular}{|c|c|c|c|c|c|}
\hline & FDI & LDR & MPR & PLR & DOP \\
\hline FDI & 1.000000 & 0.253069 & -0.311055 & -0.358080 & -0.547054 \\
\hline LDR & 0.253069 & 1.000000 & 0.121153 & -0.278005 & -0.283639 \\
\hline MPR & -0.311055 & 0.121153 & 1.000000 & 0.511559 & -0.144770 \\
\hline PLR & -0.358080 & -0.278005 & 0.511559 & 1.000000 & 0.057254 \\
\hline DOP & -0.547054 & -0.283639 & -0.144770 & 0.057254 & 1.000000 \\
\hline
\end{tabular}

Authors' computation output using E-view 10.

\section{3: Stationarity/Unit Root Test for FDI, LDR, MPR, PLR and DOP}

This procedure is normal in macroeconomic time series analysis to know the most suitable technique for estimating the model. Here, the researchers employed Augmented Dickey Fuller (ADF) unit root test as shown below;

Table 3 below shows the stationary test for both level and first difference. The results revealed that FDI, LDR, MPR and DOP are differenced once to be stationary or integrated at order one, whereas PLR is stationary at level. The variables have different orders of integration, justifying choice ARDL method. 
Table 3: ADF Unit Test

\begin{tabular}{|c|c|c|c|c|c|c|}
\hline Variables & Max & Level & $1^{\text {st }}$ Difference & Critica & Value & Remarks \\
\hline & & ADF Statistics & ADF Statistics & $5 \%$ & $10 \%$ & \\
\hline FDI & 7 & & $-5.140058(0.0002)$ & -2.963972 & -2.621007 & $@ 1(1)$ \\
\hline LDR & 7 & - & $-5.520696(0.0001)$ & -2.963972 & -2.621007 & (a) $1(1)$ \\
\hline MPR & 7 & - & $-4.335118(0.0027)$ & -2.998064 & 2.638752 & (a)1(1) \\
\hline PLR & 7 & $\begin{array}{l}- \\
3.986377(0.0045)\end{array}$ & - & -2.960411 & -2.619160 & (@) $1(0)$ \\
\hline DOP & 7 & & $-6.185385(0.0000)$ & -2.963972 & -2.621007 & @ $1(1)$ \\
\hline
\end{tabular}

Authors' computation output using E-view 10.

\section{4: Model Selection}

Figure 2 below depicts ARDL model selection based on Akaike Information Criterion (AIC). Information criteria select models that minimize their values. From figure 2 below, the best model, according to AIC, is an ARDL $(1,0,1,0,0)$. This implies that a model that includes one lagged value of the dependent variables as an additional regressor is the best description of researchers' data. Akaike Information Criteria

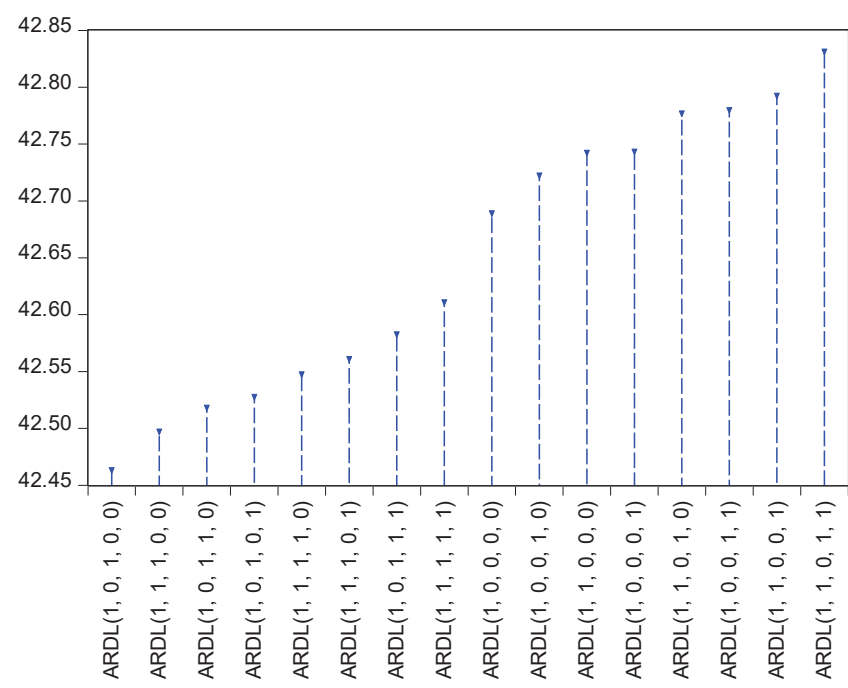

Figure 2: Model Selection based on AIC

\subsection{Model Estimation and Results}

Table 4 below shows that FDI is autoregressive at 10\% significant level. It is statistically confirmed evidence suggesting that FDI in the past can predict current and future flows of FDI in Nigeria. It is also observed that MPR and DOP have negative and significant relationship with FDI, while LDR and PLR insignificantly relate to FDI. The result of adjusted R-square indicates that the estimated ARDL $(1,0,1,0,0)$ model is moderately fitted, with the explanatory variable jointly accounting for $78.4 \%$ of total variation of FDI. The probability of FStatistic is 0.000001 , an indication that the estimated model is highly significant. The figure of Durbin-Watson Statistics (Dw) signals absence of autocorrelation. The autonomous component or constant (C) is positive and significant. This shows that there are other factors not accounted in this study that influence FDI in Nigeria. 
Table 4: ARDL Estimation Results

Dependent Variable: FDI

Method: ARDL

Selected Model: ARDL $(1,0,1,0,0)$

\begin{tabular}{|c|r|r|r|r|}
\hline Variable & Coefficient & Std. Error & t-Statistic & Prob. $^{*}$ \\
\hline FDI(-1) & 0.397592 & 0.199157 & 1.996379 & 0.0574 \\
\hline LDR & 10249178 & 7620914 & 1.344875 & 0.1912 \\
\hline MPR & -9927866 & 24194592 & -0.410334 & 0.6852 \\
\hline MPR(-1) & -67727882 & 23813978 & -2.844039 & 0.0090 \\
\hline PLR & -6977030 & 25711912 & -0.271354 & 0.7884 \\
\hline DOP & -35976082 & 9059791. & -3.970962 & 0.0006 \\
\hline C & $2.52 \mathrm{E}+09$ & $1.02 \mathrm{E}+09$ & 2.475169 & 0.0208 \\
\hline $\mathrm{R}^{2}$ & 0.784774 & Mean dependent var & & $7.56 \mathrm{E}+08$ \\
\hline Adjusted R & 0.730968 & S.D. dependent var & & $7.03 \mathrm{E}+08$ \\
\hline F-statistic & 14.58513 & Durbin-Watson stat & & 2.036148 \\
\hline Prob(F-stat) & 0.000001 & & & \\
\hline
\end{tabular}

Authors' computation output using E-view 10.

4.6 Test of long run Relationships between Monetary Policy Variables and FDI

Table 5 below shows ARDL Bound cointegration test to check if there is long run relationship in the model. From the bound test, it is clearly revealed that the F-Statistics is 4.540398 which is greater than all the critical values at $1(0)$ and $1(1)$ bounds from $1 \%$ to $10 \%$. These reject the null hypothesis of no levels of relationship, suggesting existence of long run relationship between FDI and monetary policy variables in Nigeria.

Table 5: ARDL Bound Cointegration Test

\begin{tabular}{|l|c|r|r|r|}
\hline F-Bounds Test & \multicolumn{3}{|c|}{ Null Hypothesis: No levels relationship } \\
\hline Test Statistic & Value & Signif. & $\mathrm{I}(0)$ & $\mathrm{I}(1)$ \\
\hline F-statistic & 4.540398 & $10 \%$ & 2.2 & 3.09 \\
\hline K & 4 & $5 \%$ & 2.56 & 3.49 \\
\hline & & $2.5 \%$ & 2.88 & 3.87 \\
\hline & & $1 \%$ & 3.29 & 4.37 \\
\hline
\end{tabular}

Authors' computation output using E-view 10.

\subsection{Correction Short Run Error Test}

Table 6 shows the cointegration form. As shown in the result, the error correction equation, CointEq(-1) has expected negative sign and it is significant, suggesting the ARDL model has cointegration form. It can also be seen that $60.2 \%$ of errors from the equilibrium can be corrected in the next period, and speed of adjustment is $60.2 \%$.

Table 6: ARDL Error Correction Regression

\begin{tabular}{|c|r|r|r|c|}
\hline \multicolumn{5}{|c|}{ ARDL Error Correction Regression } \\
\hline Variable & Coefficient & Std. Error & t-Statistic & Prob. \\
\hline D(MPR) & -9927866. & 17622115 & 0.000000 & 0.0000 \\
\hline CointEq(-1)* & -0.602408 & 0.104997 & -5.737411 & 0.0000 \\
\hline
\end{tabular}

Authors' computation output using E-view 10.

Next, residual diagnostic test; Normality Test, Serial Correlation Test and Heteroscedasticity Test as shown below;

\subsection{Residual Diagnostic Test}

4.8.1 Normality Test

From Table 7 below, it is seen that Jarque-Bera Statistic is 0.555511 with P- value of 0.757482 which not significant at both $5 \%$ and $10 \%$, suggesting normal distribution. 
Table 7 Normality Distribution

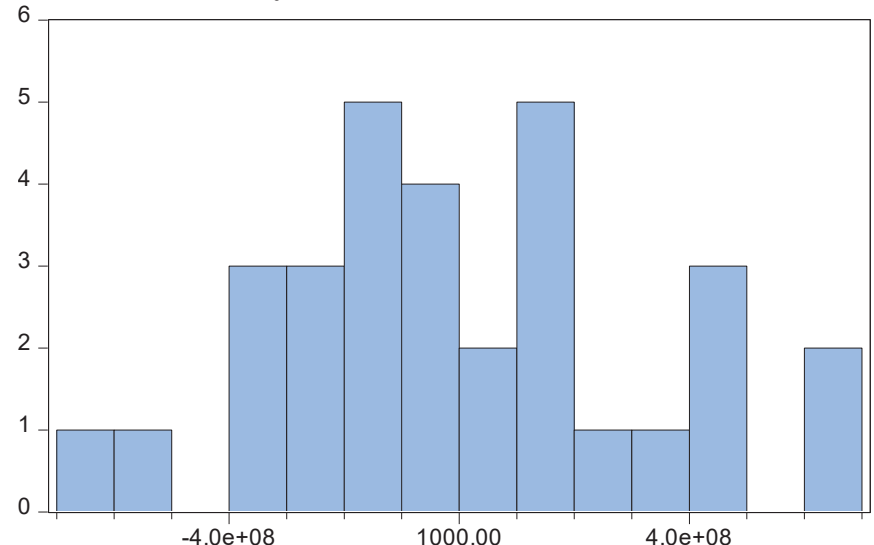

Authors' computation output using E-view 10.

\begin{tabular}{|lr|}
\hline \multicolumn{2}{|l|}{ Series: Residuals } \\
Sample 1989 2019 \\
\multicolumn{2}{|l}{ Observations 31} \\
Mean & $-8.46 \mathrm{e}-08$ \\
Median & -32424497 \\
Maximum & $6.39 \mathrm{e}+08$ \\
Minimum & $-6.67 \mathrm{e}+08$ \\
Std. Dev. & $3.26 \mathrm{e}+08$ \\
Skewness & 0.168529 \\
Kurtosis & 2.437448 \\
& \\
Jarque-Bera & 0.555511 \\
Probability & 0.757482 \\
\hline
\end{tabular}

\subsection{2: Serial Correlation Test and Heteroscedasticity Test}

The table 8 below reveals that the Heteroscedasticity Test has coefficient of F-Statistic of 0.451876 and P-value of 0.6422, suggesting homoscedasticity of the model. Breusch-Godfrey Serial Correlation LM Tests has FStatistic coefficient of 1.672737 with has P-value of 0.1710 , which shows of non rejection of the null hypothesis, confirming no serial correlation.

Table 8: Heteroscedasticity and Serial Correlation Tests

Breusch-Godfrey Serial Correlation LM Test:

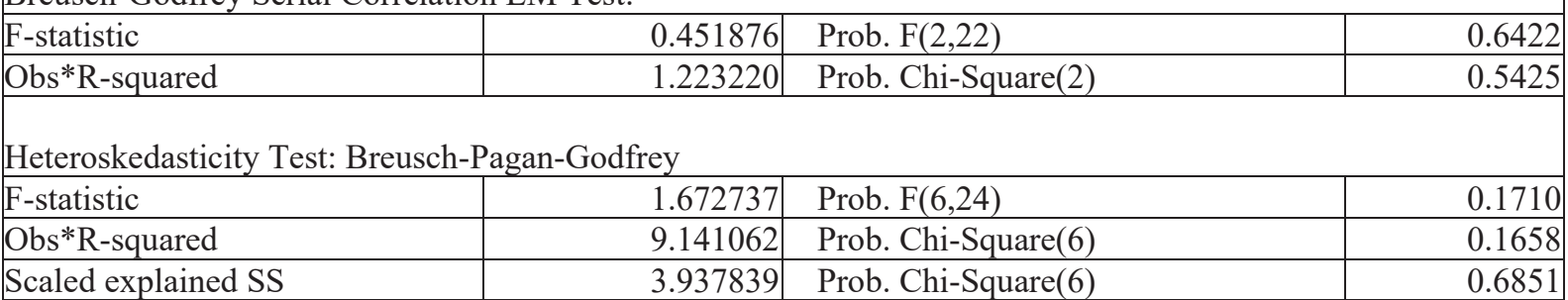

Authors' computation output using E-view 10.

\section{5: Remarks and Recommendations}

This study; sensitivity of foreign direct investment to monetary policy dynamics in Nigeria, majorly found that monetary policy rate and degree of trade openness have negative and significant relationship with foreign direct investment, while liquidity ratio and prime lending rate insignificantly relate to the foreign direct investment.

Since monetary policy rate is disclosed to significantly but negatively relate to foreign direct investment, the central bank of Nigeria should reduce further the rate in order to woo foreign investors to do business in Nigeria. Again, since globalization and trade liberalization have totally removed the issue of countries being in the state of autarky (closed economy), most of the beggars thy neighbours thy policies should be discarded at least to enhance the degree of trade openness. The central bank of Nigeria should also conduct the monetary policy with the aim of encouraging foreign investors in Nigeria.

\section{Reference}

Anna, C., Karambakuwa, R.T., Webster, D., Felex, T., Zivanai, O., Lovemore, M., \& Mudavanhu, V. (2012). The impact of interest rates on foreign direct investment: A case of Zimbabwean economy. International Journal of Management Sciences and Business Research, 1(5), 1-20

Appleyard, D.R., Field, A.J., \& Cobb, S.L.(2008). International economics (6th ed). New York, NY: Mc GrawHill Irwin.

Central Bank of Nigeria (2018) Foreign Direct Investment and the Central Bank of Nigeria’s Monetary Policy. https://www.proshareng.com/news/Monetary\%20Policy/Foreign-Direct-Investment-and-the-Central-Bankof-Nigerias-Monetary-Policy/38523

Chen, J. (2020). Prime lending rate. https://www.investopedia.com/terms/p/primerate.asp

Dare, F.D. \&Okeya, I.O. (2017). Monetary policy and commercial banks' credit performance: Evidence from UBA Plc. IOSR Journal of Economics and Finance (IOSR-JEF), 8(4), 60-67.

Echekoba, F., Ananwude, A. \& Lateef, O. (2017). Effect of monetary policy on the performance of the Nigerian capital market. Stylized facts from ARDL Approach. Advances in Research, 14(6): 1-15.

Ejem,C.A., \& Jombo, C.O. (2011). International finance. Aba: Ker Export Publisher.

Ekpung, G.E., \&Udude, C.C. \&Uwalaka, H.I. (2015). The impact of monetary policy on the banking sector in 
Nigeria. International Journal of Economics, Commercial and Management, 3(5), 1015-1031.

Hayes, A . (2019). Liquidity ratio definition. https://www.investopedia.com

Investopedia, (2020). Trade openness. https://www.investopedia.com

Ndugbu, M.O. \&Okere, P.A. (2015). Monetary policy and the performance of deposit money banks:The Nigerian experience. European Journal of Business and Management, 7(17),65-72.

Onoh, J.K. (2002). Dynamics of money, banking and finance in Nigeria: An emerging market. Aba:Astra Meridian Publishers.

Onoh, J.K. (2007). Dimension of Nigeria's monetary and fiscal policies-Domestic and external. Lagos:Astra Meridian Publishers.

Osiegbu, P.I. (2006). The level of commercial banks' compliance with CBN monetary policy credit guidelines. Journal of Social Science, 13(1), 11-14.

Policonomics, (2020).Degree of trade openness. https://policonomics.com/degree-of-openness

Rădulescu, M., Druică, E. \& Omran, A. (2012). The impact of the monetary policy factors on the foreign direct investments: Empirical evidence from Romania. Australian Journal of Basic and Applied Sciences, 6(10): 435-447

Udude, C.C. (2014). Monetary policy and economic growth in Nigeria. Journal of Policy and Development Studies, 9(1), 234-247.

Uma, K.E. (2010). International economic: An introduction. Enugu: De-Adroit Innovation.

UNCTAD (2020).WorldInvestmentReport,.https:/www.nordeatrade.com/en/explore-newmarket/nigeria/investment\#: :text=FDI\%20in\%20Figures\&text=According $\% 20$ to $\% 20$ the $\% 20$ UNCTAD $\%$ 202020,98\%2C6\%20billion\%20in\%202019.

Veugelers, R. (1991). Locational determinants and ranking of host country: An empirical assessement.Kyklos, 44(3), 363-382

World Bank's(2020)editionof Doing Business Report.https://www.nordeatrade.com/en/explorenewmarket/nigeria/investment\#: :text=FDI\%20in $\% 20$ Figures\&text=According $\% 20$ to $\% 2$ 0the\%20UNCTAD\%202020,98\%2C6\%20billion\%20in\%202019. 